\title{
HUBUNGAN ANTARA MINAT BACA DENGAN KEMAMPUAN MENYELESAIKAN SOAL CERITA MATEMATIKA KELAS III SDN TANAH TINGGI 1 KOTA TANGERANG
}

\author{
Putri Widyanti, Aam Amaliyah, Saktian Dwi Hartantri \\ e-mail: Putriwidynti98@gmail.com, aamamaliyah23@gmail.com, saktiandwihartantri@gmail.com
}

\begin{abstract}
Abstrak
Penelitian ini bertujuan untuk mengetahui hubungan antara minat baca dengan kemampuan menyelesaikan soal cerita matematika.Penelitian ini menggunakan metode penelitian kuantitatif dengan jenis penelitian survei. Populasi dalam penelitian ini adalah seluruh siswa kelas III SDN Tanah Tinggi 1 Kota Tangerang dengan populasi sebanyak 58 siswa dan sampel sebanyak 48 siswa dengan teknik pengambilan sampel menggunakan Simple Random Sampling. Instrumen penelitian yang digunakan adalah angket dan essay. Instrumen pengumpulan data untuk minat baca (variabel X) menggunakan angket Skala Likert dengan pilihan jawaban 1-4 dan kemampuan menyelesaikan soal cerita (variabel Y) menggunakan essay. Untuk pengujian hipotesis dilakukan melalui perhitungan kefisien korelasi dengan rumus Uji t. Berdasarkan rumus korelasi Product Moment dengan $\alpha=0,05$ diperoleh $t_{\text {hit }}$ 4,290 lebih besar dari $t_{\text {tab }}=2,013$ bahwa $t_{\text {hit }}>t_{\text {tab }}$ dan hipotesis diterima. Hal ini dapat diartikan bahwa terdapat hubungan antara minat baca dengan kemampuan menyelesaikan soal cerita matematika kelas III SDN Tanah Tinggi 1 Kota Tangerang.
\end{abstract}

Kata Kunci: Minat Baca, Kemampuan Menyelesaikan Soal Cerita Matematika

\begin{abstract}
This study aims to understand the relationship between reading interest and the ability to solve mathematical problems. This research uses quantitative research methods with the type of survey research. The population in this study were all students of class III SDN Tanah Tinggi 1 Tangerang City with a population of 58 students and a sample of 48 students with a sampling technique using Simple Random Sampling. The research instruments used were questionnaires and essays. Data collection instruments for reading interest (variable X) using a Likert Scale questionnaire with answer choices 1-4 and the ability to solve story problems (variable Y) using essays. To test the hypothesis, it is done by calculating the correlation efficiency with the t test formula. Based on the Product Moment correlation formula with $\alpha=$ 0.05 obtained thit 4.290 is greater than ttab $=2.013$ that thit $>$ ttab and the hypothesis is accepted. This can be interpreted that there is a relationship between reading interest and the ability to solve math problem class III SDN Tanah Tinggi 1 Tangerang City.
\end{abstract}

Keywords: Interest in Reading, Ability to Complete Mathematical Story Problems 


\section{PENDAHULUAN}

Matematika merupakan ilmu yang universal yang mendasari perkembangan teknologi modern.Matematika mempunyai peranan penting dalam berbagai disiplin dan memajukan daya pikir manusia.Matematika juga merupakan salah satu mata pelajaran yang harus di berikan mulai dari tingkat SD. Secara garis besar dalam pelajaran matematika siswa diarahkan untuk dapat memahami konsep dalam matematika dan juga dapat memecahkan masalah di dalam kehidupan sehari-hari yang berhubungan dengan matematika.Misalnya seperti soal cerita yang sering dikaitkan dengan kehidupan sehari - hari.Dalam mata pelajaran matematika, minat merupakan salah satu faktor landasan penting bagi siswa dalam menyelesaikan soal cerita di dalam pelajaran matematika. Bila seorang siswa tidak memiliki minat dan ketelitian yang besar terhadap objek yang dipelajari maka sulit diharapkan siswa tersebut akan menyelesaikan soal cerita dengan baik. Sebaliknya, apabila siswa tersebut belajar dengan minat dan ketekunan yang tinggi maka siswa dapat menyelesaikan soal cerita dengan baik. Tinggi rendahnya minat baca siswa pada mata pelajaran matematika tentunya akan memberikan pengaruh terhadap kemampuan siswa dalam menyelesaikan soal cerita.

Berdasarkan hasil observasi awal yang berupa wawancara dengan guru yang dilakukan pada tanggal 9, November 2018 di kelas III SD Negeri Tanah Tinggi 1 Kota Tangerang, khususnya kelas III B dalam pembelajaran matematika ditemukan beberapa masalah diantaranya yang berhubungan dengan siswa, yaitu dimana minat baca siswa sangat kurang dalam mengerjakan soal cerita, terdapat beberapa siswa yang mengobrol dengan temannya dan memilih melihat pekerjaan temannya atau mencontek hasil pekerjaan temannya. Kemudian yang berhubungan dengan guru sebagai sumber belajar, dimana guru masih membimbing siswa dalam mengerjakan soal cerita seperti membacakan soal cerita tersebut dan memberitahukan cara-caranya karena ada beberapa siswa yang belum dapat membaca dengan lancar atau masih mengeja dan ada beberapa siswa juga yang belum bisa memahami soal tersebut.

Berdasarkan data yang diperoleh di SDN Tanah Tinggi 1 Kota Tangerang pada pembelajaran matematika kelas III B dengan jumlah 27 dari 28 siswa diperoleh dari nilai tes siswa dengan Kriteria Ketuntasan Minimal (KKM) untuk mata pelajaran matematika yang harus diperoleh adalah 70. Maka diketahui bahwa siswa yang mendapatkan nilai lebih dari KKM hanyalah 6 siswa atau 22,2\% sedangkan yang mendapatkan nilai rata - rata KKM 3 siswa atau $11,1 \%$ dan siswa yang belum mencapai KKM sebanyak 18 siswa atau 66,7\%, 
adapun siswa yang mencapai nilai tertinggi yaitu 100 sedangkan siswa yang mendapatkan nilai terendah yakni 0 . Hal tersebut disebabkan oleh guru yang selalu membimbing siswa dalam mengerjakan soal cerita seperti guru selalu membacakan soal cerita tersebut terlebih dahulu membuat siswa menjadi malas untuk membaca, guru selalu memberi tahukan caracara penyelesaian soal cerita beserta jawabannya, kurangannya minat baca siswa dikarenakan kemampuan membaca siswa yang masih rendah dan kemampuan pemahaman siswa terhadap soal cerita.

Rumusan penelitian yang dibuat peneliti adalah Apakah terdapat hubungan antara minat baca dengan kemampuan menyelesaikan soal cerita matematika kelas III di SDN Tanah Tinggi 1 Kota Tangerang. Manfaat yang didapat diambil dari penelitian ini yaitu menambah wawasan ilmu pengetahuan tentang minat baca siswa, menambah pengetahuan tentang kemampuan menyelesaikan soal cerita pada mata pelajaran

\section{KAJIAN TEORI}

\section{Pengertian Kemampuan Menyelesaikan Soal Cerita Matematika}

Menurut Mariani, (2018:4). "Kemampuan menyelesaikan soal cerita matematika merupakan kesanggupan yang dimiliki seseorang untuk memecahkan masalah yang berupa soal cerita matematika yang disajikan dalam bentuk cerita dan berhubungan dengan hal-hal yang kongkret serta berkaitan dengan kehidupan sehari-hari peserta didik".Dengan demikian, kemampuan menyelesaikan soal cerita adalah kemampuan yang dimiliki siswa untuk mencari pemecahan masalah yang berkaitan dengan kehidupan sehari-hari sehingga didapat solusi (jawaban) yang tepat.

Menurut Winarni dan Harmini (2016:125) "Dalam memecahkan masalah kita dituntut untuk berpikir dan bekerja keras menerima tantangan agar mampu memecahkan masalah yang kita hadapi. Rumus, teorema, hukum, aturan pengerjaan, tidak dapat secara langsung digunakan dalam pemecahan masalah, karena antara masalah yang satu dan masalah yang lain tidak selalu sama dalam penyelesaiannya. Dengan demikian seseorang dituntut untuk menyelesaikan masalah dengan menggunakan berbagai cara yang berbeda, karena setiap masalah yang dihadapi selalu berbeda, begitu pula cara menyelesaikan masalahnya, Seperti penggunakan rumus matematika.

Berdasarkan uraian di atas, maka dapat disimpulkan bahwa kemampuan menyelesaikan soal cerita adalah kesanggupan atau kecakapan siswa yang berasal dari dalam diri siswa untuk mencari pemecahan masalah yang terdapat pada soal cerita yang berkaitan 
dengan keadaan yang dialami siswa dalam kehidupan sehari-hari sehingga didapat solusi (jawaban) yang tepat. Permasalahan yang timbul diubah menjadi bentuk kalimat matematika dan menggunakan oprasi hitung dalam mencari solusinya.

\section{Pengertian Minat Baca}

Menurut Sudarsana (2014: 13) menyatakan "Minat baca merupakan perpaduan antara keinginan, kemauan, dan motivasi, yang dapat di kaitkan sebagai dorongan yang timbul, gairah atau keinginan besar pada diri manusia yang menyebabkan seseorang menaruh perhatian pada kegiatan membaca". Dengan demikian minat baca adalah suatu gabungan antara keinginan dan pembinaan untuk memunculkan rasa keinginan untuk seseorang melakukan kegiatan membaca.

Menurut Dalman (2017:142), "Minat baca merupakan aktivitas yang dilakukan dengan penuh ketekunan dalam rangka membangun pola komunikasi dengan diri sendiri untuk menemukan informasi untuk mengembangkan intelektual yang dilakukan dengan penuh kesadaran dan perasaan senang yang timbul dari dalam dirinya".Dengan demikin minat baca adalah keinginan yang kuat dari seseorang untuk menemukan suatu informasi guna membangkitkan kemampuan intelektual seorang pembaca.

Berdasarkan uraian di atas dapat disimpulkan bahwa minat baca adalah suatu keinginan yang timbul dalam diri seseorang untuk menemukan suatu informasi guna membangkitkan pemahaman seorang pembaca.

\section{METODOLOGI PENELITIAN}

Metode penelitian yang diguanakan dalam penelitian ini adalah metode penelitian kuantitaif survei dengan teknik deskripsi korelasi. Pada penelitian ini peneliti ingin melihat ada tidaknya hubungan antara minat baca dengan kemampuan menyelesaikan soal cerita siswa kelas III. Dalam penelitian ini seluruh siswa Kelas III SD Negeri Tanah Tinggi 1 Kota Tangerang yang merupakan populasi penelitian kelas III A sebanyak 30 siswa dan III B sebanyak 28 siswa dengan Jumlah Total 58 siswa. Pengambilan sampel dalam penelitian ini dilakukan dengan teknik sampel acak sederhana atau simple random sampling.Menurut Sugiyono (2015: 75) Sampel acak sederhana yaitu peneliti mengambil sampel dari populasi dilakukan secara acak terhadap semua populasi.Jumlah sampel yang diteliti menggunakan Table Krejcie. Teknik pengumpulan data merupakan cara yang dilakukan peneliti dalam mengumpulkan data penelitiannya. Dalam melaksanakan kegiatan penelitian deskripsi korelasi teknik pengumpulan data yang peneliti lakukan sebagai berikut; 


\section{Teknik Tes}

Pada penelitian ini peneliti akan memberikan soal uraian (essay) untuk melihat kemampuan siswa menyelesaikan soal cerita Matematika.

\section{Angket}

Angket yang akan digunakan sebanyak 25 butir pernyataan yang akan dijawab oleh siswa. Angket ini menggunakan Skala Likert.Dalam instrumen penelitian telah disediakan alternatif jawaban dari butir pertanyaan dan responden dapat memilih satu dari 4 jawaban yang sesuai. Untuk pertanyaan positif, bila jawabannya selalu $=4$; sering $=3$; pernah $=2$; tidak pernah; 1 . Sementara untuk pertanyaan negatif, bila jawabannya selalu $=1$; sering $=$ $2 ;$ pernah $=3 ;$ tidak pernah $=4$.

\section{HASIL PENELITIAN DAN PEMBAHASAN}

Hasil akhir pengolahan data tersebut dapat diketahui banyaknya jumlah pernyataan yang akan digunakan dalam penelitian untuk variabel $\mathrm{X}$ yaitu 20 soal yang valid, sedangkan untuk variabel Y yaitu 10 soal yang valid.

\section{Analisis Deskripsi Data Variabel Y}

Analisis deskripsi data dilakukan dengan cara penghitungan manual. Dapat dilihat pada tabel 4.1.

Tabel 1.

Ukuran Pemusatan Data Kemampuan Menyelesaikan Soal Cerita Matematika

\begin{tabular}{|c|l|c|}
\hline No. & \multicolumn{1}{|c|}{ Ukuran Data } & Nilai \\
\hline 1. & Jumlah Sampel (N) & 48 \\
\hline 2. & Data Tertinggi (Dmax) & 93 \\
\hline 3. & Data Terendah (Dmin) & 39 \\
\hline 4. & Rentang Data (R) & 54 \\
\hline 5. & Banyak Kelas (K) & 7 \\
\hline 6. & Interval Data (I) & 8 \\
\hline 7. & Mean (X) & 68,8 \\
\hline 8. & Median (Me) & 72,7 \\
\hline 9. & Modus (Mo) & 66,1 \\
\hline 10. & Varians (S $)$ & 38,5 \\
\hline 11. & Standar Deviasi (S) & 11,4 \\
\hline
\end{tabular}

Pada tabel 1 dapat dilihat data kemampuan menyelesaikan soal cerita matematika diperoleh melalui instrumen penelitian berupa soal cerita matematika dengan jumlah sampel 48 siswa, skor tertinggi 93, dan skor terendah yaitu 39, sehingga didapat rentang data sebesar 54, banyak kelas yaitu 7 dan interval data sebesar 8 , kemudian didapat mean atau rata-rata 
skor dari kemampuan menyelesaikan soal cerita yaitu 68,8 dengan median atau nilai tengahnya yaitu 72,7 Sedangkan nilai yang sering muncul atau biasa disebut dengan modus yaitu 66,1. Kemudian dapat diketahui variansnya sebesar 38,5 dan standar deviasi atau simpangan bakunya sebesar 11,4.

Berdasarkan hasil perhitungan interval, diketahui nilai interval sebesar 8, sehingga dapat dilihat distribusi frekuensi variabel Y pada table 2.

\section{Tabel 1}

\section{Distribusi Data Kemampuan Menyelesaikan Soal Cerita Matematika}

\begin{tabular}{|c|c|c|c|c|c|}
\hline No. & $\begin{array}{c}\text { Interval } \\
\text { Kelas }\end{array}$ & Tepi Kelas & $\mathbf{F}$ & $\begin{array}{c}\mathbf{X} \text { (titik } \\
\text { tengah) }\end{array}$ & $\begin{array}{c}\text { F Relatif } \\
(\%)\end{array}$ \\
\hline 1 & $39-46$ & $38,5-46,5$ & 2 & 42,5 & $4,2 \%$ \\
\hline 2 & $47-54$ & $46,5-54,5$ & 2 & 50,5 & $4,2 \%$ \\
\hline 3 & $55-62$ & $54,5-62,5$ & 9 & 58,5 & $18,8 \%$ \\
\hline 4 & $63-70$ & $62,5-70,5$ & 14 & 66,5 & $29,2 \%$ \\
\hline 5 & $71-78$ & $70,5-78,5$ & 10 & 74,5 & $20,8 \%$ \\
\hline 6 & $79-86$ & $78,5-86,5$ & 10 & 82,5 & $20,8 \%$ \\
\hline 7 & $87-93$ & $86,5-93,5$ & 1 & 90 & $2,1 \%$ \\
\hline \multicolumn{2}{|c|}{ Jumlah } & & $\mathbf{4 8}$ & & $\mathbf{1 0 0} \%$ \\
\hline
\end{tabular}

\section{Analisis Data}

\section{Uji Normalitas Data Kemampuan Menyelesaikan Soal Cerita Matematika (Variabel} Y)

Pengujian normalitas kemampuan menyelesaikan soal cerita matematika dilakukan dengan rumus Chi Kuadrat.

Tabel 3

Hasil Uji Normalitas Data Kemampuan Menyelesaikan Soal Cerita Matematika

\begin{tabular}{|c|c|c|}
\hline \multirow{2}{*}{ Variabel Y } & $\chi_{\text {hitung }}^{2}$ & $\chi_{\text {tabel }}^{2}$ \\
\cline { 2 - 3 } & 4,794 & 14,067 \\
\hline
\end{tabular}

Berdasarkan tabel 3 di atas terlihat bahwa $\chi^{2}$ hitung pada variabel Y lebih kecil dari $\chi^{2}$ tabel, maka $\mathrm{H}_{0}$ diterima artinya sampel berasal dari populasi yang berdistribusi normal.

\section{Uji Normalitas Data Minat Baca (Variabel X)}

Tabel 4.4

Hasil Uji Normalitas Data Minat Baca

Variabel Y

$\chi_{\text {hitung }}^{2}$

$\chi_{\text {tabel }}^{2}$ 


\begin{tabular}{|l|l|l|}
\hline & 11,681 & 12,838 \\
\hline
\end{tabular}

Berdasarkan tabel 4.8 di atas terlihat bawah $\chi^{2}$ hitung pada variabel $\mathrm{X}$ lebih kecil dari $\chi^{2}$ tabel, maka $\mathrm{H}_{0}$ diterima sehingga sampel berasal dari populasi yang berdistribusi normal.

\section{Uji Homogenitas Variabel $X$ dan $Y$}

Uji Homogenitas dilakukan untuk mengetahui apakah data yang didapat dari varians variabel X dan Y. Pengujin homogenitas ini menggunakan Uji Fisher.

\section{Tabel 4.5}

Hasil Uji Homogenitas Variabel X dan Y

\begin{tabular}{|l|c|c|}
\hline \multirow{2}{*}{ Variabel X dan Y } & $\mathbf{F}_{\text {hitung }}$ & $\mathbf{F}_{\text {tabel }}$ \\
\cline { 2 - 3 } & 1,077 & 1,624 \\
\hline
\end{tabular}

Berdasarkan tabel 4.9 di atas terlihat hasil perhitungan uji homogenitas dengan menggunakan rumus Uji Fisherbahwa $\mathrm{F}_{\text {hitung }}$ lebih kecil dari $\mathrm{F}_{\text {tabel }}$ maka dapat disimpulakan bahwa kedua sampel berasal dari populasi yang homogen.

\section{Persamaan Regresi}

Berdasarkan data dapat diketahui nilai $\Sigma \mathrm{X}=3060, \Sigma \mathrm{Y}=3297$, dan $\Sigma \mathrm{X}^{2}=199170$, $\Sigma Y^{2}=232462$. Sedangkan rata-rata skor $X$ adalah 63,75 dan rata-rata skor $Y$ adalah 68,82 . Setelah diketahui perhitungan data regresi sederhana kedua variabel, maka hasil data tersebut akan kembali di hitung menggunkan rumus peramaan regresi $\hat{Y}=a+b x$. Analisis regresi sederhana antara variabel X (Minat Baca) dan variabel Y (Kemampuan Menyelesaika Soal Cerita Matematika) menghasilkan koefisien arah regresi sebesar 0,65 dan konstanta sebesar 27,42. Dengan demikian berdasarkan rumus tersebut didapat persamaan regresi sebagai berikut: $\hat{\mathrm{Y}}=27,42+0,65 \mathrm{x}$, bentuk hubungan antara variabel $\mathrm{X}$ (minat baca) dan variabel $\mathrm{Y}$ (kemampuan menyelesaikan soal cerita matematika) artinya jika minat baca (X) naik satu satuan maka kemampuan menyelesaikan soal cerita (Y) dapat diprediksikan akan meningkat sebesar $0,65 \%$ pada konstanta 27,42 .

\section{Uji Linieritas dan Uji Signifikansi Regresi}

Selanjutnya dilakukan uji signifikansi dan linieritas model regresi minat baca dengan kemampuan menyelesaikan soal cerita matematika. Untuk mengetahui uji liniearitas dan uji signifikansi regresi maka harus dihitung menggunakan analisis varians. Berikut ini disajikan tabel anova atau analisis varians regresi: 
Tabel 4.6

Analisis Varians

\begin{tabular}{|c|c|c|c|c|c|c|}
\hline $\begin{array}{l}\text { Sumber } \\
\text { Varians }\end{array}$ & Db & JK & RJK & $\mathbf{F}_{\text {hitung }}$ & $\mathbf{F}_{\text {tab }}$ & $\begin{array}{c}\text { Kesimpulan } \\
\text { Data }\end{array}$ \\
\hline Total & 48 & 232462 & - & - & - & - \\
\hline $\begin{array}{l}\text { Regresi (a) } \\
\text { Regresi (b/a) } \\
\text { Sisa (s) }\end{array}$ & $\begin{array}{c}1 \\
1 \\
46\end{array}$ & $\begin{array}{l}226463 \\
1773,66 \\
4225,34\end{array}$ & $\begin{array}{c}226463 \\
1773,66 \\
91,86\end{array}$ & 19,309 & 4,052 & $\begin{array}{c}\text { Regresi } \\
\text { Signifikansi }\end{array}$ \\
\hline $\begin{array}{l}\text { Tuna Cocok (Tc) } \\
\text { Galat }(\mathrm{G})\end{array}$ & $\begin{array}{l}21 \\
25\end{array}$ & $\begin{array}{r}463,38 \\
3761,96 \\
\end{array}$ & $\begin{array}{r}22,07 \\
150,48\end{array}$ & 0,146 & 1,995 & $\begin{array}{l}\text { Regresi } \\
\text { Liniear }\end{array}$ \\
\hline
\end{tabular}

Berdasarkan hasil pengujian pada tabel 4.10 diperoleh $F_{\text {hitung }}=0,146<\mathrm{F}_{\text {tabel }}=1,995$ dengan ketentuan $\mathrm{F}_{\text {hitung }}<\mathrm{F}_{\text {tabel }}$ maka regresi linier, sedangkan untuk uji signifikansi diperoleh $F_{\text {hitung }}=19,309>F_{\text {tabel }}=4,052$ dengan ketentuan $F_{\text {hitung }}>F_{\text {tabel }}$ maka signifikan. Dengan demikian dapat disimpulkan bahwa bentuk hubungan antara minat baca (X) dengan kemampuan menyelesaikan soal cerita matematika (Y) adalah linier dan signifikansi. Dengan kata lain bahwa minat baca mempunyai hubungan dengan kemampuan menyelesaikan soal cerita matematika.

\section{Pengujian Hipotesis}

\section{Uji Koefisien Korelasi}

Tabel 4.7

Hasil Uji Koefisien Korelasi

\begin{tabular}{|l|c|c|}
\hline \multirow{2}{*}{ Variabel X dan Y } & $\mathbf{r}_{\mathbf{x y}}$ & $\mathbf{r}_{\text {tabel }}$ \\
\cline { 2 - 3 } & 0,534 & 0,284 \\
\hline
\end{tabular}

Berdasarkan rumus Product Moment pada tabel 4.11 didapat hasil $\mathrm{r}_{\mathrm{xy}}$ sebesar 0,534 dan $r_{\text {tabel }}$ sebesar 0,284 dengan $(\mathrm{df}=46)$ dan taraf signifikansi $5 \%$, sehingga $r_{\text {hitung }}>r_{\text {tabel }}$ maka $\mathrm{H}_{0}$ ditolak dan $\mathrm{H}_{1}$ di terima yang berarti bahwa terdapat hubungan antara minat baca dengan kemampuan menyelesaikan soal cerita matematika pada siswa kelas III SDN Tanah Tinggi 1 Kota Tangerang.

\section{Uji Signifikansi Korelasi}

Tabel 4.8

Hasil Uji Signifikansi Koefisien Korelasi 


\begin{tabular}{|c|c|c|}
\hline \multirow{2}{*}{ Variabel X dan Y } & $\mathbf{t}_{\text {hitung }}$ & $\mathbf{t}_{\text {tabel }}$ \\
\cline { 2 - 3 } & 4,290 & 2,013 \\
\hline
\end{tabular}

Berdasarkan uji t maka didapat nilai $t_{\text {hitung }}$ sebesar 4,290dan $t_{\text {tabel }}$ sebesar 2,013 $(\mathrm{df}=$ 46). Karena $t_{\text {hitung }}>t_{\text {tabel }}$ maka $\mathrm{H}_{0}$ ditolak dan $\mathrm{H}_{1}$ diterima yang berarti terdapat hubungan yang signifikan antara minat baca dengan kemampuan menyelesaikan soal cerita matematika pada siswa kelas III SDN Tanah Tinggi 1 Kota Tangerang.

\section{Koefisien Determinasi}

Koefisien determinasi merupakan langkah terakhir dari analisis data penelitian. Penghitungan ini dilakukan untuk mengetahui kontribusi variabel $\mathrm{X}$ dan variabel $\mathrm{Y}$, dengan $r_{x y}=0,534$, sehingga hubungan antara minat baca dengan kemampuan menyelesaikan soal cerita matematika determinasi variasi kemampuan menyelesaikan soal serita yang ditentukan oleh minat baca sebesar 28,52\% kelas III SDN Tanah Tinggi 1 Kota Tangerang dengan model regresi $\mathrm{Y}=27,42+0,65 \mathrm{x}$, ternyata cukup signifikan.

Berdasarkan hasil perhitungan statistik yang telah dilakukan dapat diketahui, bahwa terdapat hubungan yang positif signifikan antara minat baca dengan kemampuan menyelesaikan soal cerita matematika sekolah dasar kelas III SDN Tanah Tinggi 1 Kota Tangerang.Hal ini sesuai dengan perumusan hipotesis yang mengatakan bahwa apakah terdapat hubungan antara minat baca dengan kemampuan menyelesaikan soal cerita matematika kelas III di SDN Tanah Tinggi 1 Kota Tangerang.

Hasil pengujian hipotesis memuktikan bahwa minat baca memiliki hubungan positif yang signifikan dengan kemampuan menyelesaikan soal cerita matematika sekolah dasar kelas III. Hal tersebut menunjukan bahwa siswa yang memiliki minat baca yang baik akan mampu menyelesaikan soal cerita matematika dengan baik. Tingginya minat baca memberikan peluang bagi siswa untuk lebih memahami kalimat matematika yang terdapat dalam soal cerita.Siswa dapat menentukan langkah-langkah penyelesaian soal cerita.Dengan demikian siswa memahami kaitannya antara soal cerita dengan langkah penyelesaian.

Hasil penelitian menunjukkan bawah terdapat hubungan positif yang signifikan antara minat baca dengan kemampuan menyelesaikan soal cerita matematika yang dinyatakan dalam bentuk persamaan regresi $\hat{Y}=27,42+0,65 x$. Sedangkan berdasarkan uji koefisien korelasi Product Momentyanghasilnya $\mathrm{r}_{\text {hitung }}$ yaitu 0,534 , dan selanjutnya dibandingkan dengan nilai $\mathrm{r}_{\text {tabel }}$ dengan $\mathrm{df}=46$ taraf signifikansi, maka dalam penelitian ini diperoleh $\mathrm{r}_{\text {hitung }}=0,534>$ 
$\mathrm{r}_{\text {tabel }}=0,284$ dengan demikian $\mathrm{H}_{1}$ diterima yang berarti bahwa terdapat hubungan positif antara minat baca dengan kemampuan menyelesaikan soal cerita matematika kelas III SDN Tanah Tinggi 1 Kota Tangerang.

Adapun hasil dari pengujian signifikansi korelasi dengan rumus uji t telas diperoleh nilai $t_{\text {hitung }}=4,290$ dan $t_{\text {tabel }}=2,013$. Hal ini berarti $t_{\text {hitung }}>t_{\text {tabel }}$ sehingga $H_{1}$ diterima yang berarti bahwa terdapat hubungan yang signifikan antara minat baca dengan kemampuan menyelesaikan soal cerita matematika kelas III SDN Tanah Tinggi 1 Kota Tangerang.

Hal ini ditunjukan oleh koefisisen determinasi variasi kemampuan menyelesaikan soal serita yang ditentukan oleh minat baca sebesar 28,52\%. Hal ini menandakan bahwa kemampuan menyelesaikan soal cerita matematika memiliki keterkaitan dengan minat baca sebesar 28,52\% sedangkan sisanya 71,48\% ditentukan oleh faktor lain seperti, kurangnya kemampuan membaca siswa, konsentrasi siswa dalam membaca dan kurangnya siswa dalam mengoperasikan perkalian. Berdasarkan hasil penelitian tersebut sesuai dengan teori dalam memecahkan masalah kita dituntut untuk berfikir dan bekerja keras menerima tantangan agar mampu memecahkan masalah yang kita hadapi.Berfikir dan bekerja keras mampu memecahkan suatu masalah dalam soal cerita dengan tepat.Memecahkan suatu masalah dalam soal diperlukan sebuah ketelitian agar dapat memperoleh suatu jawaban yang benar dan akurat.Terdapat beberapa siswa ketika menulis hal-hal yang diketahui, ditanyakan, dan jawaban tidak lengkap sehingga mempengaruhi nilai.Beberapa siswa tidak dapat menghitung waktu, hal ini disebabkan kurangnya konsentrasi dan ketelitian siswa dalam menyelesaikan soal cerita matematika. Hal tersebut menunjukan siswa yang memiliki minat yang tinggi terhadap bacaan, maka akan mudah dalam memahami masalah sehingga dapat menyelesaikan soal cerita dengan baik. Artinya jika siswa memiliki minat baca yang tinggi, maka akan diikuti dengan kemampuan menyelesaikan soal cerita matematika yang baik. Begitu sebaliknya, apabila siswa memiliki minat baca yang rendah.Dengan ini minat baca sangat berpengaruh terhadap kemampuan menyelesaikan soal cerita matematika.

Siswa yang gemar membaca akan memiliki banyak pengetahuan sehingga dalam mencari jawaban dari soal cerita siswa tidak terpaku hanya pada satu jalan saja, namun siswa dapat menemukan cara lain yang berakhir pada jawaban yang tepat dan akurat. Melalui membaca membantu siswa dalam melatih keterampilan membaca soal cerita sehingga informasi yang terdapat dalam soal dapat dipahami siswa dengan mudah.Sehingga anggapan siswa tentang menyelesaikan soal cerita matematika sebagai pelajaran yang sulit dan 
membosankan lama kelamaan dapat memudah menjadi soal cerita matematika sebagai perjalanan yang mudah dan menyenangkan.

\section{KESIMPULAN DAN SARAN}

\section{Kesimpulan}

Berdasarkan hasil perhitungan pada pengujian hipotesis penelitian yang dilakukan di SDN Tanah Tinggi 1 Kota Tangerang kelas III pada tahun ajaran 2018/2019dengan sampel 48 siswa didapatkan hasil koefisien korelasi antara minat baca dengan kemampuan menyelesaikan soal cerita matematika sebesar $t_{\text {hitung }}=4,290$ dengan $t_{\text {tabel }}=2,013$ untuk taraf signifikansi sebesar 0,534. Maka berdasarkan kriteria pengujian $H_{0}$ ditolak jika $t_{\text {hitung }}>t_{\text {tabel }}$ dan $\mathrm{H}_{0}$ diterima jika $t_{\text {hitung }}<t_{\text {tabel }}$, maka dari data di atas dapat dilihat $t_{\text {hitung }}>t_{\text {tabel }}$ dan $r_{x y}>0$, hal ini menunjukan bahwa terdapat hubungan positif signifikan antara minat baca dengan kemampuan menyelesaikan soal cerita matematika sekolah dasar kelas III pada SDN Tanah Tinggi 1 kota Tangerang.

Pada penghitungan koefisien korelasi determinasi yang diperoleh sebesar 0,2852. Hal ini berarti kemampuan menyelesaikan soal cerita matematka ditentukan oleh minat baca sebesar $28,52 \%$ sedangkan $71,48 \%$ di tentukan oleh faktor lain seperti kurangnya kemampuan membaca dan konsentrasi membaca pada siswa serta kurangnya kemampuan mengoperasikn perkalian. Hasil mengujian hipotesis menunjukan bahwa minat baca memiliki hubungan positif signifikan dengan kemampuan menyelesaikan soal cerita matematika SD Kelas III.Siswa yang memiliki minat baca yang tinggi akan membantu dalam memahami petanyaan yang terdapat dalam soal cerita matematika. Siswa yang terbiasa membaca akan lebih mudah memahami soal cerita dibandingkan dengan siswa yang memiliki minat baca rendah. Siswa yang gemar membaca akan memiliki banyak pengetahuan sehingga dalam memecahkan masalah dari soal cerita kemudian juga siswa tidak terpaku hanya dengan satu jalan saja namun siswa dapat menentukan dengan cara lain yang berakhir pada jawaban yang tepat dan akurat. Dengan membaca membantu siswa dalam melatih keterampilan membaca soal cerita sehingga informasi yang terdapat dalam soal cerita tersebut dapat dipahami siswa dengan mudah. Siswa akan beranggapan tentang soal cerita matematika sebagai pelajaran yang sulit dan membosankan tetapi lama kelamaan dapat menganggap bahwa soal cerita matematika sebagai pelajaran yang mudah dan menyenangkan. 


\section{Saran}

Berdasarkan hasil penelitian yang menunjukan hubungan positif antara minat baca dengan kemampuan menyelesaikan soal cerita matematika peneliti ingin memberikan saran yang mudah-mudahan dapat diterima oleh semua pihak yang terkait sebagai berikut:

\section{a. Bagi Guru}

1) Hendaknya guru memberikan perhatian lebih kepada siswa yang belum dapat membaca dengan lancar agar siswa tetap mampu menyelesaikan soal-soal cerita matematika.

2) Hendaknya guru selalu memberikan motivasi kepada siswa sebelum memulai pembelajaran agar siswa mampu mempersiapkan diri dan memiliki semangat yang tinggi untuk belajar.

3) Hendaknya guru memberikan latihan soal secara intensif agar siswa termotivasi untuk membuka buku pelajaran sehingga akhirnya mereka mampu dengan mudah memahami materi yang di ajarkan.

\section{b. Bagi Siswa}

1) Hendaknya siswa sering membaca agar mengembangkan kemampuan membaca siswa sehingga minat baca siswa dapat meningkat.

2) Hendaknya siswa memperbanyak latihan soal-soal agar dapat dengan mudah siswa untuk menjawab soal-soal cerita matematika.

\section{DAFTAR PUSTAKA}

Arikunto, S. (2013). Prosedur Penelitian. Jakarta: PT Rineka Cipta. (2018). Dasar-Dasar Evaluasi Pendidikan. Jakarta: Bumi Aksara.

Dalman. (2017). Keterampilan Membaca . Jakarta: PT Rajagrafindo Persada .

Desmita. (2017). Psikolog Perkembangan Peserta Didik. Bandung: PT Remaja Rosdakarya.

Harlin, A. T. (2015). Hubungan Antara Kemampuan Membaca Pemahaman dengan Kemampuan Menyelesaikan Soal Cerita Matematika Siswa Kelas IV SDN Se-Gugus 3 Imogiri Bantul . Universitas PGRI Yogyakarta, 2-3.

Irwansyah, N., \& Mukhtar. (2013). Buku Mata Kuliah Membaca. Tangerang: PT Pustaka Mandiri.

Isrok'atun, \& Rosmala, A. (2018). Model-Model Pembelajaran Matematika. Jakarta: Bumi Aksara.

Kreitner, R., \& Kinicki, A. (2014). Perilaku Organisasi. Jakarta: Salemba Empat. 
Kuadrat, H. B. (2014). Mengelola Kecerdasan Dalam Pembelajaran. Jakarta: PT Bumi Aksara.

Mariani, A. (2018). Hubungan Kemampuan Membaca Pemhaman dengan Kemampuan Menyelesikan Soal Cerita Matematika SD Kelas IV SDN 1 Selebung Ketangga . Universitas Mataram, 6-7. http://eprints.unram.ac.id/6137/1/JURNAL.pdf

Nur'Aeni. (2012). Hubungan Kemampuan Membaca Pemahaman dan Minat Belajar Matematika Dengan Kemampuan Penyelesaian Soal Cerita Siswa Kelas IV SD SeKecanatan Klirong Tahun 2011/2012. Universitas Negeri Sebelas Meret, 2.

Rahim, F. (2018). Pengajaran Membaca di Sekolah Dasar. Jakarta: PT Bumi Aksara.

Riadi, E. (2015). Metode Statistika Parametrik \& Nonparametrik untuk penelitian ilmuOilmu sosial dan pendidikan. Tangerang: PT Pustaka Mandiri.

Robbins, S., \& Judge, T. (2017). Perilaku Organisasi. Jakarta: Salemba Empat.

Slameto. (2015). Belajar dan Faktor-Faktor yang Mempengaruhi . Jakarta: PT Rineka Cipta.

Solikhah, I. A. ( 2016). Hubungan Minat Baca dengan Hasil belajar Bahasa Indonesia Siswa kelas V SDN Gugus Dipayuda Kec. Banjarnegara Kab. Banjar Negara . Universitas Negeri Semarang, 8.

Sudarsana, U. (2014). Materi Pokok Pembinaan Minat Baca 1-9. Tangerang Selatan: Universitas Tebuka .

Sugiyono. (2010). Statistika Untuk Penelitian. Bandung: Alfabeta.

Sugiyono. (2015). Metode Penelitian Pendidikan. Bandung : Alfabeta. (2016). Metode Penelitian Kuantitatif, Kualitatif, dan R\&D. Bandung: Alfabeta.

Susanto, A. (2013). Teori Belajar dan Pembelajaran di Sekolah Dasar. Jakarta: Prenadamedia. 